\title{
A Semiotics Analysis On The Use Of Emoticons In Inter-Personal Communication On Facebook Social Media
}

\author{
A G Y Sompotan ${ }^{1}$ \\ ${ }^{1}$ Universitas Negeri Manado, Indonesia \\ corresponding author: ameliasompotan@unima.ac.id
}

\begin{abstract}
Facebook social media is one of the most popular social media in various circles, ranging from teenagers to adults using this application. Facebook is one place to share expressions or information that is in great demand. One of the facilities available on Facebook is emoticons. Currently Facebook users use emoticons to express their feelings as a sign of response to an upload made by someone else as a message sender. There are various kinds of emoticons in the Facebook application such as love, smile, lauge, flower and many more. Each emoticon is a sign that has an object and raises an interpretant in the minds of users of this application. The method used in this study is descriptive qualitative with the technique of collecting data on observation, interviews, documentation studies and literature studies. The results of this study are descriptive data analysis of the meaning contained in the use of emoticons is to reinforce the contents of the message, provide support, insinuate someone, express feelings of sadness or feelings of joy, feeling embarrassed, giving encouragement or encouragement, apologizing and expressing gratitude. The use of emoticons must be appropriate so there is no mistaken interpretation of the recipient of the message.
\end{abstract}

Keywords: Emoticons; Meanings; Semiotics; Social Media; Facebook.

\section{Introduction}

The development of the current era of globalization, has changed the pattern of human life to become increasingly sophisticated and modern and easy. This cannot be denied because as technology develops in terms of communicating, someone sends a message no longer using telegrams or letters but uses the latest communication and information technology such as communication via mobile phones. Communication technology that is developing at this time can connect longdistance communication without having to face face to face, and can be done anywhere anytime without knowing the time limit.

The presence of social media such as Facebook can state that humans cannot escape from technology. As human social beings, they need to interact with others. One of the media used to interact is social media in this case Facebook. Social media is able to answer the needs of people interacting, collaborating and showing their existence in the social sphere. Facebook's social networking site has become a social 
phenomenon, introducing connected people and building long-distance relationships (and sometimes forgetting) friends and colleagues (Mitra, 2010: 48).

Even though Partners assume that social media users sometimes forget friends and colleagues, people flock their profiles on social media. One of the most widely used social media is Facebook. On Facebook someone can communicate verbally and non-verbally. One feature that can be used when people chat and are considered as representatives of the feelings of the other person is the use of emoticons. Basically, emoticons are a symbol or a combination of symbols that are usually used to describe human facial expressions that contain emotions or feelings in the form of messages or writing. The word emoticon is actually etymologically a combination of two words in English, namely emotion, which means emotion, and icon, which means symbol. Facebook users in message exchange activities not only send messages through a series of letters, but insert emoticons in communication as a form of response to messages received. In the use of emoticons sometimes there are differences in meaning in replying to messages. The emoticons that are widely used on Facebook are smile, anger, thumbs, love.

\section{Picture 1}

An example of emoticon in Facebook social media

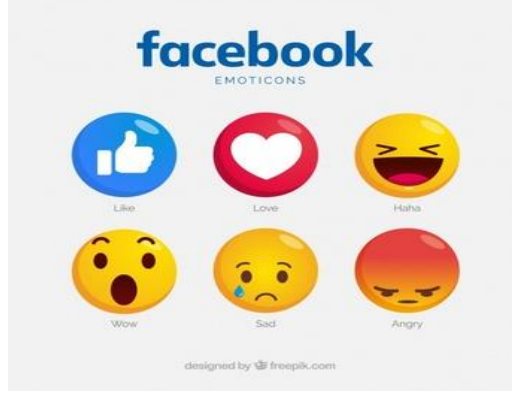

\section{Problem Formulation}

Based on the background above, the problem is formulated as follows: What is the meaning of emoticons in interpersonal communication on Facebook social media.

\section{Objectives and Benefits of Research}

Starting from the problems stated in the previous section, the purpose of this research is to find out the meaning of emoticons in interpersonal communication on Facebook social media. The benefit of research is that it can develop linguistic studies in this regard with the use of meaning through symbols (emoticons).

\section{Literature Review}

\section{Meaning}

Meaning is an inseparable part of semantics and is always inherent from whatever we say. Understanding of meaning itself is very diverse. Mansur Pateda (2001) suggests that the term meaning is confusing words and terms. In the linguistic dictionary, the term meaning becomes: a) the intention of the speaker, b) the influence of the application of language in the use of human or group perceptions or behavior, c) the relationship in the meaning of 
equivalence between the language or the expression and everything it shows, d) how to use symbol of language.

\section{Semiotic}

Semiotics can be defined as the science of sign. CharlesMoris distinguishes three semiotic types: syntactic, semantic and pragmatic (Parera 2004: 10). Semiotics is the science of signs. Semiotics comes from Greek, namely semeion, which means sign. Signs are defined as something that on the basis of conventional social development beforehand, can be considered to represent something else. Tanda is the basis of all communication. A sign signifies something other than itself, and meaning is the relationship between an object and an idea and a sign. Signs caused by humans are verbal and nonverbal. Signs caused by speech tools are called verbal signs while nonverbal signs are signs that use limbs. In Pierce's triangle theory there are three main elements forming a sign, namely sign / representamen (sign), object (object), and interpretant (interpretan). Peirce argues that one form of sign is a word while an object is something that is referred to by a sign. While interpretan is a sign in someone's mind about the object referred to by a sign. If these three elements react in a person's mind then the meaning arises about something represented by the sign (Najib 2014: 425).

Based on Pierce's theory, the sign in gmabar can be seen from the types of signs classified in semiotics. Pierce divides the sign into icons, indices and symbols. A sign is something that represents something. Something can be in the form of ideas or ideas or feelings. Signs can also be experiences or thoughts. For example, A is a black smoke that reaches in the distance, then A can represent B which is a fire. Such marks can be referred to as indexes between A and B. Signs can also be symbols or symbols, for example the spoon and fork symbol of a restaurant. Spoons and forks cannot be replaced by other items.

The icon is the relationship between signs and objects that are similar in nature. An icon is a physical object that resembles what is presented. For example the sura and baya statue is an icon of the city of Surabaya.

An index is a sign that has a causal relationship with what it represents. For example footprints on the floor indicate an index of people passing through that place. Symbols are signs based on conventions, regulations or agreements that are mutually agreed upon. For example the Manguni bird is a symbol of the Minahasa community. The relationship between icons, indices and symbols is conventional.

\section{Research Methods}

The method used in this study is descriptive qualitative. Qualitative research is research that intends to understand the phenomenon of what is experienced by the subject of research, for example behaviors, perceptions, motivations, actions and others in a holotic manner and by way of descriptions in the form of words and language, in a context especially natural and by utilizing various natural methods. (Maleong 2005: 6) 


\section{Data Collection Techniques}

Data collection techniques carried out in this study were

1) Observation, is the collection of data by making observations directly on the object of research or location to see the reality in place which is the object of research.

2) Interview, is to obtain information or a clearer picture of the object to be examined by holding a question and answer directly to the respondents using interview techniques.

3) The documentation study, is to get a complete picture of using emoticon stickers on Facebook social media.

4) Literature study is a method of collecting data to obtain information through books and literature related to this research.

\section{Data Analysis}

Techniques that have been used to analyze data that have been available are adjusted to the research objectives. At first the researchers made a thorough observation on the emitikon on Facebook social media that represents the feelings of communicants in delivering messages. Emoticons found were analyzed further to obtain reasons why they existed and were used. (Foley 1997)

\section{Results and Discussion}

Emoticons used in conversations on Facebook are not only to represent feelings of anger, pleasure, sadness or happiness but rather as a confirmation of the contents of the text or message sent.

1) Emoticon in the form of a grimace.

Based on emoticon research, a grimace in the face shows a nervous or shy / awkward expression but it can also respond to funny conversations.

Example: Moga2 hari ini urusan lancar

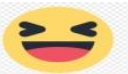

In the message the sender uses emoticons of a grimace representing an expression of feeling nervous or awkward. Based on Charles Pierce's semiotic analysis, the use of emoticons is categorized in symbols. According to Odgen and Ridchard in Chaer (2013: 38) that the symbol or symbol is conventional, an agreement, but it can be organized, recorded and communicated.

2) Emoticon embrace

The embrace emoticons used in sending meaningful messages support what the sender of the message does or also hug emoticons have a love symbol for the message sender or message recipient.

Example: Graduation....SMANTO...Auditorium Bukit Inspirasi Tomohon...congrats Debora

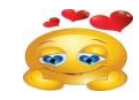

In the message the sender of the message uses hugging emoticons while smiling to give a message that the message sender provides support or support. In addition to emoticons, hugging sometimes the message sender 
also uses emoticons clapping both hands to give support. Using the right emoticon in sending messages will make communication well interwoven. Conversely the use of emoticons that is less appropriate will make a misunderstanding in communication. Interpersonal communication is the process of sending and receiving messages between two individuals or between individuals in groups with some effects and instant feedback.

3) Use sad emoticons.

Sadness or nelangsa is an emotion that is characterized by feelings of luck, loss, and helplessness.

Example: Ma ola pE bae pa qta, nda bakalan qta mo lupa

In the text message above the use of emoticons means deep sadness because it was abandoned by a loved one during life. The emotion of the crying face hiccups is indicated by tears coming out. Facebook application has provided various face-shaped features to represent the emotions or feelings of its users. But please note that not all emoticons that emit tears mean sadness. when the message is inserted with this emoticon, the sender is happy or funny. Aditya Firmansyah (2010: 10) suggests that social networking sites are a servicebased site that allows users to create profiles, view a list of available users, and contain or accept friends to join the site. Every social network has its own charm. But basically networking or social media aims to communicate easily and more interesting because it is equipped with features in the form of emoticons that pamper users.

4) The use of angry emoticons.

Anger is a feeling of disappointment with oneself or others. Based on emoticon research used to express disappointment, hurt, anger is to use red face emoticons. The face is red like a fire indicating the anger of the sender of the message. For example: can't wash the clothes so that the lights are metong.

The sender of the message must be observant in choosing emoticons that represent his feelings. Each emoticon has many meanings. If the sender of the message carelessly uses emoticons to trigger a misunderstanding of the meaning that will damage friendship.

5) Use of emoticons to express feelings of gratitude

Based on emoticon research, the most appropriate request is to represent a feeling of gratitude for achievement, namely with a symbol

These emoticons cannot be used to insinuate others. These emoticons can be used on positive things. Apologies can also use these emoticons. These emoticons are application.

\section{Conclusion}

Based on the data analysis that has been stated, it can be concluded that sending text messages using Facebook has meaning to emoticons that are used, among others, to:

1. Strengthen the message

2. Provide support 
Journal of Educational Method and Technology Vol. 2 No. 1, April 2019

P-ISSN 2622-8459 E-ISSN 2622-8467

http://ejournal.unima.ac.id/index.php/jemtec

3. Apology

4. Express feelings of gratitude

5. Express feelings of anger

6. Give enthusiasm

7. Express feelings of sadness / disappointment

The users of social media Facebook are greatly helped by the presence of emoticons with various forms that can represent their feelings. The use of emoticons in sending messages can also save time because they no longer type letter by letter. Message delivery is only via emoticons. Facebook applications are currently the most users of applications.

\section{References}

Chaer, Abdul.2013.Pengantar Semantik Bahasa Indonesia.Jakarta;Rineka Cipta Foley,A.W.1997.Antropological linguistics: AnIntroduction. Oxford, England: Blackwell Publiser Ltd

John,L.Stephen,W.2009.Teori Komunikasi Theories of Human Communication Edisi 9.Jakarta;Salemba

Maleong,L.2005.Metodologi Penelitian Kualitatif.Bandung:Remaja Rosdakarya

Mitra,A.2010.Digital Communications:From E-mail to the Cyber Community.New York:Chelsea House Publisher

Naji,M.2014.eJournal Ilmu Komunikasi,Volume 2 No.3.ISSN 00000000.ejounal,ilkum.fisip.inmul.ac.id

Parera,J.D.2004.Teori Semantik.Jakarta:Erlangga

Pateda,Mansoer.1987. Sosiolinguistik. Bandung: Penerbit Angkasa 